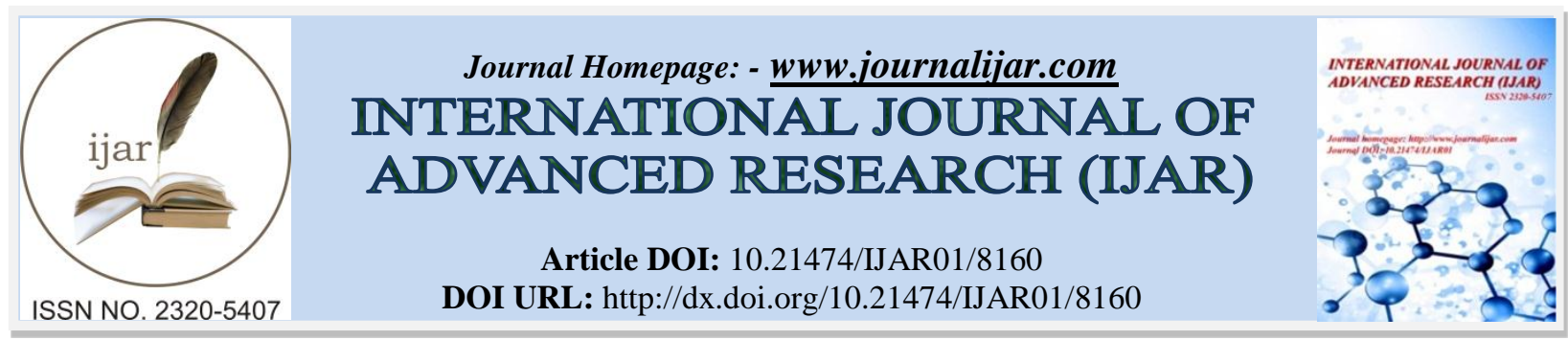

RESEARCH ARTICLE

\title{
SWOT ANALYSIS OF MIXED OWNERSHIP REFORM IN POWER GRID ENTERPRISES: A CASE STUDY IN WESTERN INNER MONGOLIA.
}

Liu Jicheng ${ }^{1}$, Fu Xiaoxu ${ }^{1}$ and Yu Jing ${ }^{2}$.

1. School of Economics and Management,North China Electric Power University,Beijing, China.

2. Beijing Key Laboratory of New Energy and Low-Carbon Development,North China Electric Power University,Beijing,China.

\section{Manuscript Info}

\section{Manuscript History}

Received: 04 October 2018

Final Accepted: 06 November 2018

Published: December 2018

Keywords:

Mixed Ownership Reform, SWOT

Analysis, Power Grid Enterprises.

\section{Abstract}

Mixed ownership reform and reform of electric power system have brought new opportunities and challenges to the development of China's power grid enterprises. Taking Inner Mongolia West Power Grid as an example, this paper uses SWOT analysis method to analyze the internal strengths and weaknesses, external opportunities and threats faced by the company in carrying out the reform and development of mixed ownership. On this basis, it puts forward countermeasures and suggestions, in order to further promote the healthy and rational development of power grid enterprises.

Copy Right, IJAR, 2018,. All rights reserved.

\section{Introduction:-}

In 2013, the Third Plenary Session of the Eighteenth Central Committee of the Communist Party of China decided to set up a leading group to deepen reform in an all-round way so as to make the market play a decisive role in the allocation of resources. In 2015, the Central Committee of the Communist Party of China and the State Council issued Guiding Opinions on Deepening the Reform of State-owned Enterprises, which put forward clear opinions on the objectives and principles of the reform, the promotion of reform and the development of mixed ownership economy. The reform of state-owned capital investment and operation companies and mixed ownership has become the key measures in this round of reform. Since then, a number of policy documents have been issued, such as Opinions on the Development of Mixed Ownership Economy in State-owned Enterprises, Opinions on the Pilot Employee Stock Ownership in State-owned Holding Mixed Ownership Enterprises, and more specific provisions have been formulated from the aspects of classification of state-owned enterprises, hierarchical reform, reform of state-owned assets management system, non-state-owned capital participation in mixing and employee stock ownership. All these have constructed the basic policy framework for promoting the mixed reform of state-owned enterprises. On March 15, 2015, the Central Committee of the Communist Party of China and the State Council issued a document entitled "Several Opinions on Further Deepening the Reform of the Electric Power System" (No. 9 of the Central Committee of the Communist Party of China [2015]), which began a new round of electricity market-oriented reform. Subsequently, six supporting documents were issued, and detailed deployments were made in the key areas of transmission and distribution price, trading mechanism, and power side reform, which paved the way for a new round of electricity reform in terms of system[1-3].

Power grid enterprises are one of the most important main bodies in the power market. Implementing mixed ownership reform and capital investment operation, giving full play to the technological advantages of strategic

Corresponding Author:-Yu Jing.

Address:-School of Economics and Management,North China Electric Power University,Beijing 
emerging industries and professional fields, and exploiting industrial investment, project cultivation and equity investment will become an effective complement and important force for the strategic development of power grid enterprises. It is of great significance for realizing sustainable development under the background of new electricity reform and promoting the transformation and development of local resource-based economy.

SWOT (Strength, weaknesses, opportunities, Threats) analysis model is a widely used and effective analysis method, which is very helpful to industry development research [4-6]. Some scholars have used SWOT analysis to study the development of power industry [7-8], photovoltaic industry [9], and power grid enterprises [10-11]. Taking Inner Mongolia West Power Grid as an example, this paper uses SWOT analysis model to make a comprehensive analysis of the internal and external conditions of the company's mixed ownership reform from four aspects: advantages, disadvantages, opportunities and threats. On this basis, it puts forward countermeasures and suggestions , which provide the basis for the company to formulate the next reform strategy and promote the Inner Mongolia power grid enterprises development.

\section{Overview of Inner Mongolia West Power Grid Company}

Inner Mongolia West Power Grid Company (hereinafter referred to as Company) is a state-owned super-large power grid enterprise in Inner Mongolia Autonomous Region. It is responsible for the construction and operation of power grids in eight alliance cities in the central and western regions of the Autonomous Region. It has a power supply area of 720,000 square kilometers and serves more than 13.8 million people. Over the years, the company has achieved steady growth in production and operation indicators, and has maintained a stable situation in safety production. The annual electricity sales have exceeded the plan, and the customer satisfaction has reached $98 \%$. By 2017 , the company mainly consists of power supply production and business support units, including 12 power supply production units, 10 branch companies, 12 subsidiaries and 2 holding companies.

The company plays the roles of the main body of investment and financing, the main body of major project construction and the main body of the safe operation of the western Inner Mongolia power grid. It is responsible for investment, construction and management of the western Inner Mongolia power grid; operation of related transmission and distribution business; participation in investment, construction and operation of related trans-regional transmission and transformation and networking projects; engaged in power purchase and sale business; management of power trading and dispatching at home and abroad; independently carry out foreign trade circulation business, international cooperation, foreign project contracting and foreign labor service cooperation and other business.

With the strategic transformation and innovation of the company, the production and operation mechanism of the company has changed greatly in the past two years. The company is market-oriented and gradually promotes the construction of market-oriented mechanism and governance structure. It explores the reform of state-owned enterprises, vigorously integrates internal and external resources, and actively promotes industrial restructuring and business transformation and upgrading. Business-oriented, it adheres to customer interests first, improve customer experience, enhance customer satisfaction. it continuously strengthens the management consciousness and strives to improve the management situation. The company has broadened the living space, opened the development channel, and gradually laid down the strategic layout of " laying stress on specific functions of the main industry, diversified development of the industry".

\section{SWOT Analysis of Mixed Ownership Reform in Inner Mongolia West Power Grid Company Strengths \\ High attention from management.}

The success of the reform of mixed ownership in state-owned enterprises depends largely on the attention of management. Since the promulgation of the mixed ownership reform policy, the company has actively responded to the national policy, calling on relevant departments and enterprises to formulate the mixed ownership reform strategy and carry out feasibility study.

\section{Brand resources and customer resources advantages.}

For a long time, the company has been serving the construction and operation of power grids in eight alliance cities in the central and western part of Inner Mongolia Autonomous Region. Since its establishment, it has a close relationship with governments at all levels, has established a good cooperative relationship with power generation enterprises, and has established a good corporate image and brand. At the same time, its power supply reliability is over $99.5 \%$. It 
continues to rank first among the top 30 enterprises in the autonomous region and has monopolistic customer resources. These provide market and resource advantages for company to carry out mixed ownership reform.

\section{Geography and location advantage.}

Inner Mongolia straddles northeast, north and northwest China, adjacent to eight provinces and regions, and handed over with Russia and Mongolia. The unique location advantage of Inner Mongolia determines that it has a large number of business opportunities in the power grids Interconnection, power trade, power supply and power grid project development, construction and operation of one of the four routes along the "one belt and one road".These has created conditions for expanding overseas business markets and reforming mixed ownership.

\section{Strong financial strength.}

The company has strong financial strength and good investment ability. It has the ability to fight for new resources and acquire the resources in stock. At the same time, it can attract private capital and foreign capital investment to a large extent.

\section{Advantages of information resources.}

The company is familiar with the operation characteristics of power system, and has obvious advantages in information resources such as power grid development planning, power distribution, user load characteristics and so on. These provide strong support for the subsequent establishment of mixed ownership companies.

\section{Talents and technical advantages.}

The company has technical advantages in planning, dispatching, operation, marketing, maintenance, equipment management, safety management and so on. Private enterprises just lack experience in this field.

\section{Scale advantage of new energy development.}

The Mongolian West Power Grid actively supports and promotes the development of new energy such as wind power, and has become one of the fastest growing areas of new energy in the country. The installed scale of wind power and generation capacity are among the leading indicators in the country. In the area of distributed energy, it provides a basis for the implementation of mixed ownership strategy.

\section{Weaknesses}

Relative lack of flexibility.

Major decisions need to be declared to companies at all levels, which may lead to insufficient flexibility and relatively low decision-making efficiency in formulating and implementing mixed ownership reform strategies, which is not conducive to perceiving the market and seizing opportunities in complex and changeable external environment.

Talent structure is relatively unreasonable, and incentive mechanism needs to be further improved.

According to the situation of the subsidiaries of the company, the number of high-level technical talents and skilled talents is insufficient, and the number of financial, business, management, computer and other professionals and compound talents is relatively scarce. The incentive mechanism of reward and punishment, the guiding mechanism of talent flow and the scientific career planning are not perfect. The system of talent selection, employment, education and retention needs to be improved, and the mechanism of talent selection and employment needs to be further improved.

\section{Opportunities}

Macroeconomic policy regulation and control provides policy environment.

Inner Mongolia is an important energy base in China. Building a strong Inner Mongolia power grid is not only the need of Inner Mongolia's economic development, but also the need of the country to realize the optimal allocation of energy resources. Therefore, the government adopts various macro-control policies to adjust the energy industry structure, accelerate the pace of renewable energy development and utilization, and provide a good policy environment for the development of Inner Mongolia power grid.

First, the further deepening of Reform of Electric Power System brings new opportunities for the development of Inner Mongolia power grid. Second, West Development Strategy has created a loose development platform for the development of Inner Mongolia power grid. Thirdly, on March 19, 2013, when the leaders of Inner Mongolia Autonomous Region carried out the systematic elaboration on the development of Inner Mongolia Autonomous 
Region, they put forward the development ideas, namely "eight constructions", "three efforts", "three more emphasis" and "seven key tasks", which created a broader development space for Inner Mongolia power grid.

\begin{abstract}
New energy and new technology bring new space for company business expansion and industrial chain extension.

New technologies such as distributed energy supply, energy storage technology and electric vehicles have emerged and been applied successively. New energy, represented by wind energy, solar energy and other clean energy, has developed rapidly. Business models such as virtual power plant, demand side management and contract energy management have been innovating constantly, which provides opportunities for the company and its subsidiaries to further enrich the connotation of traditional business and expand business space. In addition, the development of smart grid technology will be conducive to further enhance the reliability, flexibility and scalability of power grid system, and improve the efficiency of power grid operation. At the same time, the huge demand of modern society for communication and information industry, the closer integration of Finance and industry provide opportunities for the company to exert own advantages, expand business scope and extend the industrial chain.
\end{abstract}

\title{
Business opportunities in distribution and electricity sale market.
}

With the gradual deepening of the new electricity reform, potential business opportunities emerge in the distribution market. Implementing the reform of mixed ownership can bring in the information resources, technical resources, management and market-oriented consciousness of social capital such as private enterprises, improve the company's financial resources and comprehensive competitiveness to varying degrees, and then seize the distribution and electricity sale market.

\section{Standardizing enterprise operation and attracting excellent talents.}

Participation in the reform of mixed ownership can help more subsidiaries standardize the governance structure, improve the management system, and improve operational efficiency.

\section{Threats}

Opening up of power sale and strict supervision of power transmission and distribution price put forward higher requirements for the company's business quality, and face the risk of loss of important customers.

Introducing competition mechanism on the selling side will change the monopoly situation of power supply of power grid enterprises and break the exclusive power purchase pattern of power grid enterprises, which will directly reduce the income of power grid enterprises, and will inevitably have a huge profit impact on Inner Mongolia power grid. At the same time, new technologies such as the liberalization of power selling side and the combination of energy storage and distribution in the new power reform have led to the phenomenon of "load off-line" or even "user off-line".

\section{Diversification of business entities and intensification of market competition.}

At present, after the Reform of Electric Power System, the power selling side is opened up, and new customers are proposed. In the initial stage of electricity sales business, the competing objects are mainly the current industrial users, commercial users and so on, and these customers are the best value customers of power grid enterprises. According to statistics, the core profit of power grid enterprises comes from $20 \%$ of its large industrial users, which contributes more than $60 \%$ of the profits of power grid enterprises. Incremental distribution network is an important part of the "orderly liberalization of distribution and electricity sale market" in the new electricity reform. The distribution sector will gradually be liberalized to social capital. The introduction of competition mechanism will inevitably impact the original monopoly pattern of power grid.

After the reform of the electric power system, five new competitors have been added, including: High-tech industrial parks or economic and Technological Development zones; social capital; distributed power generation or microgrid systems; public service industries and energy-saving service companies such as water supply, gas supply and heating; power generation enterprises. If the grid company is added, there will be six kinds of competition in the electricity market after the electricity reform. Five types of new competitors and basic competition strategies are added to the electricity reform as shown in Figure 1. 


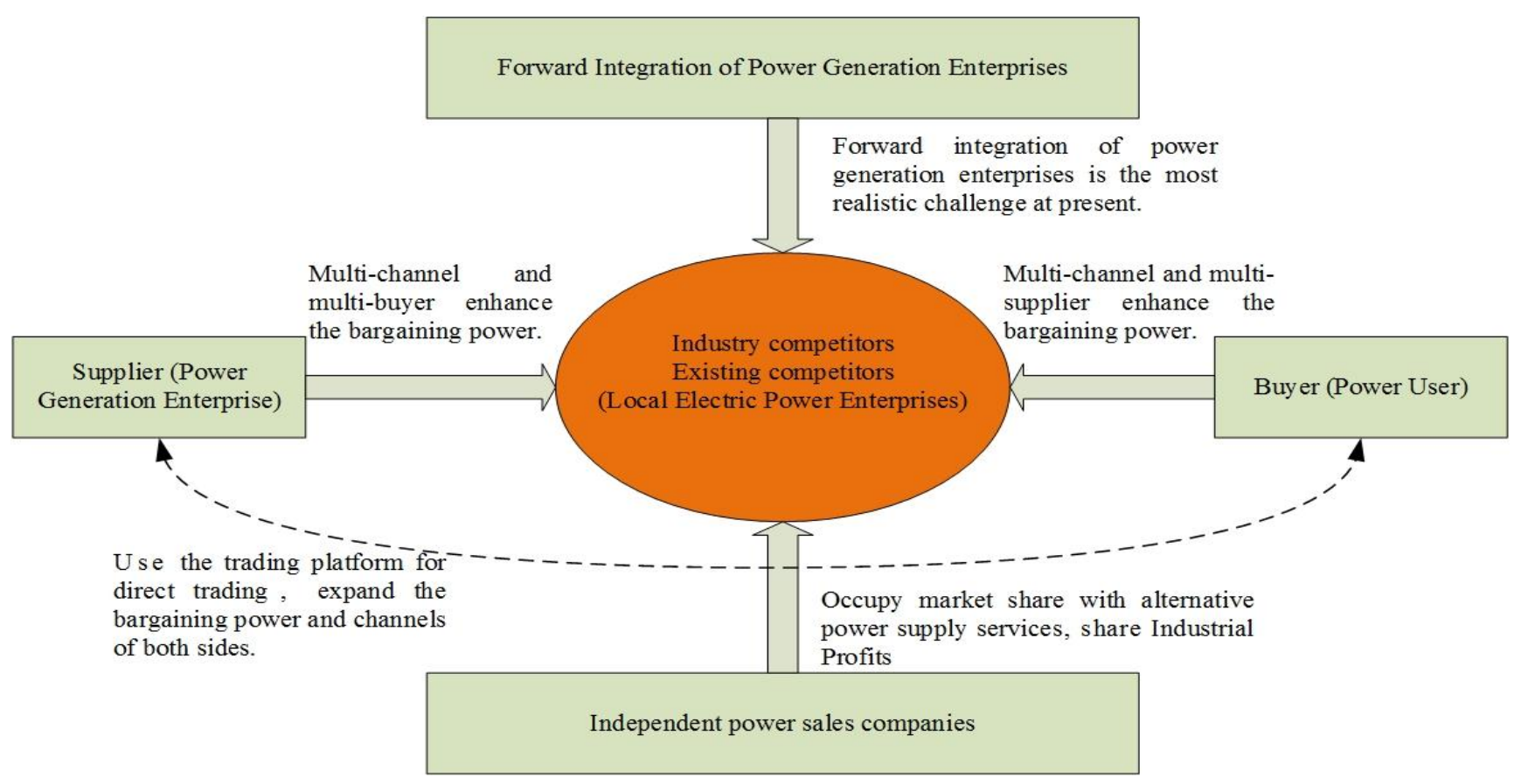

Fig 1:-Five types of new competitors and basic competition strategies

With the gradual advancement of reform, the liberalization of the power selling side has formed a strong expectation in the market, which will strengthen the competition mechanism at the power selling side and form a new marketoriented electricity selling mechanism. The reform of transmission and distribution price will help to promote the process of competitive electricity market and provide a basis for the establishment of market-oriented pricing mechanism of power prices. This will introduce more market competitors to the distribution side and form a marketoriented pricing mechanism. From a strategic point of view, the ultimate state of the electricity market will show such important characteristics as differentiation, cost leadership, regional focus (niche market) and full coverage.

In addition, local energy platforms (provincial and municipal energy companies) will benefit most from this round of state-owned enterprise reform, and these enterprises will also join the competition in the power industry through their advantages in resource integration to intensify market competition.

\section{Conclusion and suggestions:-}

To sum up, the advantages, disadvantages, opportunities and threats of the company's mixed ownership reform are summarized. According to the results of SWOT analysis, corresponding development suggestions and strategies are put forward, as shown in Table 1.

Based on the above analysis, we suggest that companies should actively explore the reform of mixed ownership and state-owned capital investment and operation mode, and focus on guiding subsidiaries to advance the reform of mixed ownership in an orderly manner under the unified planning and deployment of company. In accordance with the overall development plan of "prominent main industries and diversified industries", and market-oriented, the reform of mixed ownership has taken substantive steps.

\section{Acknowledge:-}

This research was supported by National Natural Science Foundation of China (Grant No. 71771085). 
Table 1:-SWOT Anylasis Result, Development Suggestions and Strategies

\begin{tabular}{|c|c|c|c|}
\hline & Internal conditions & Strengths & Weaknesses \\
\hline $\begin{array}{l}\text { External } \\
\text { environment }\end{array}$ & & $\begin{array}{l}\text { 1. High attention from management. } \\
\text { 2. Brand resources and customer } \\
\text { resources advantages. } \\
\text { 3. Geography and location advantage. } \\
\text { 4. Strong financial strength. } \\
\text { 5. Advantages of information } \\
\text { resources. } \\
\text { 6. Talents and technical advantages. } \\
\text { 7. Scale advantage of new energy } \\
\text { development. }\end{array}$ & $\begin{array}{l}\text { 1. Relative lack of flexibility. } \\
\text { 2. Talent structure is relatively } \\
\text { unreasonable, and incentive } \\
\text { mechanism needs to be further } \\
\text { improved. }\end{array}$ \\
\hline \multirow[t]{2}{*}{ Opportunities } & \multirow[b]{2}{*}{$\begin{array}{l}\text { 1. Macroeconomic policy } \\
\text { regulation and control } \\
\text { provides policy environment. } \\
\text { 2. New energy and new } \\
\text { technology bring new space } \\
\text { for company business } \\
\text { expansion and industrial chain } \\
\text { extension. } \\
\text { 3. Business opportunities in } \\
\text { distribution and electricity } \\
\text { sale market. } \\
\text { 4. Standardizing enterprise } \\
\text { operation and attracting } \\
\text { excellent talents. }\end{array}$} & S-O Strategies & W-O Strategies \\
\hline & & $\begin{array}{l}\checkmark \text { Strengthen investment in power } \\
\text { grid construction based on major } \\
\text { industries. } \\
\checkmark \text { Promoting } \\
\text { Development of Cross-regional } \\
\text { Transportation. } \\
\checkmark \text { Strengthen deep-seated } \\
\text { cooperation with Mongolia and } \\
\text { Russia and actively develop } \\
\text { international business. } \\
\checkmark \text { Reasonable expansion of the } \\
\text { industrial chain and selective } \\
\text { involvement in new technologies } \\
\text { and new energy business areas. }\end{array}$ & $\begin{array}{l}\checkmark \text { Strengthen the adjustment of } \\
\text { talent structure, improve the } \\
\text { incentive mechanism and give } \\
\text { full play to the advantages of } \\
\text { the platform. } \\
\checkmark \text { Strengthen the capacity of } \\
\text { overall and coordinated } \\
\text { allocation of resources. } \\
\checkmark \text { Increase investment in } \\
\text { distribution and rural power } \\
\text { grids. }\end{array}$ \\
\hline \multirow[t]{2}{*}{ Threats } & \multirow[b]{2}{*}{$\begin{array}{l}\text { 1. Opening up of power sale } \\
\text { and strict supervision of } \\
\text { power transmission and } \\
\text { distribution price put forward } \\
\text { higher requirements for the } \\
\text { company's business quality, } \\
\text { and face the risk of loss of } \\
\text { important customers. } \\
\text { 2. Diversification of business } \\
\text { entities and intensification of } \\
\text { market competition. }\end{array}$} & S-T Strategies & W-T Strategies \\
\hline & & $\begin{array}{l}\checkmark \text { Provide customers with } \\
\text { diversified and personalized } \\
\text { services. } \\
\checkmark \text { Changing the Development } \\
\text { Mode to Benefit Management. } \\
\checkmark \text { Grasp the company's unique } \\
\text { position and give full play to its } \\
\text { own advantages. }\end{array}$ & $\begin{array}{l}\checkmark \text { Implementing integrated and } \\
\text { standardized management to } \\
\text { realize lean management. } \\
\checkmark \text { Pay attention to scientific and } \\
\text { technological innovation, } \\
\text { improve the level of power grid } \\
\text { security, enhance core } \\
\text { competitiveness, and do a good } \\
\text { job of technical reserve. }\end{array}$ \\
\hline
\end{tabular}

\section{References:-}

1. Li B B. Key Issues in the Reform of Mixed Ownership in State-owned Enterprises [J]. Friends of Accounting, 2018.

2. Xu G G, Sun W. Five key issues in the reform of mixed ownership of state-owned enterprises [J]. Macroeconomic management, 2018 (1).

3. Li X J. Problems and Suggestions for Deepening the Reform of Mixed Ownership [J]. Modern Management Science, 2018 (8).

4. Huang X B, Jiang X J. Dynamic Improvement of SWOT Strategic Analysis Model [J]. Information Theory and Practice, 2009, 32 (7): 78-81.

5. Chang H H , Huang W C . Application of a quantification SWOT analytical method[J]. Mathematical \& Computer Modelling, 2006, 43(1):158-169.

6. Hill T, Westbrook R. SWOT Analysis: Time for a Product Recall[J]. 1997.

7. Li J Y. Research on Development Strategy of China's Power Market Under Energy Internet [J]. Electrotechnics Electric, 2018 (10): 64-69. 
8. Zhou C Y, Feng Y M, L J. Research and SWOT Analysis on Swedish Power Sector [J]. International Engineering and Labor Services, 2018 (10): 52-54.

9. Zhao Y N. SWOT analysis and Countermeasures for the development of photovoltaic industry in China [J]. Rural Economy and Science-Technology, 2018,29(16): 105-106.

10. Yin Q. SWOT Analysis and Strategic Choice of Comprehensive Budget Management for Power Grid Enterprises [J]. Chinese and Foreign Entrepreneurs, 2018 (13): 34

11. Chen H B. Analysis of the development of power grid enterprises under the background of the new round of power system reform [J]. China Market, 2017 (10): 176-177. 